\title{
Assessment of Dry Port Efficiency in Africa Using Data Envelopment Analysis
}

\author{
Hamadou Tahirou Abdoulkarim ${ }^{1}$, Seydou Harouna Fatouma ${ }^{2}$, Hamadou Tahirou Hassane ${ }^{3}$ \\ ${ }^{1}$ School of Economics and Management, Shanghai Maritime University, Shanghai, China \\ ${ }^{2}$ Glorious Sun School of Business and Management, Donghua University, Shanghai, China \\ ${ }^{3}$ School of Health and Management, Abdou Moumouni Dioffo University, Niamey, Niger \\ Email: *kalishufe@hotmail.com
}

How to cite this paper: Abdoulkarim, H.T., Fatouma, S.H. and Hassane, H.T. (2019) Assessment of Dry Port Efficiency in Africa Using Data Envelopment Analysis. Journal of Transportation Technologies, 9, 193-203.

https://doi.org/10.4236/jtts.2019.92012

Received: March 23, 2019

Accepted: April 8, 2019

Published: April 11, 2019

Copyright (c) 2019 by author(s) and Scientific Research Publishing Inc. This work is licensed under the Creative Commons Attribution International License (CC BY 4.0).

http://creativecommons.org/licenses/by/4.0/

\begin{abstract}
This work involves the evaluation of dry port competitiveness through analysis of efficiencies for selected dry ports in Africa. Five dry ports were selected and analysis carried out over a period of four years. The dry ports considered were Mojo and Kality in Ethiopia, Mombasa in Kenya, Isaka in Tanzania and Casablanca in Casablanca, Morocco. Data Envelopment Analysis (DEA) was applied for this work. Container throughputs for the various ports under consideration were used as the output variable for the data analysis model, while the number of reach stackers, the number of tractors, the number of forklifts and the size of the dry port were used as the input variables. From the results, the Mombasa dry port was found to be the most efficient with an average score of approximately 1 over the period under consideration. Casablanca was the second efficient dry port with an average score of 0.762 , while Isaka was the least efficient with an average score of 0.142 . This research is significant since the African countries have embraced the dry port concept, as witnessed in the huge investments in this sector, and would serve to highlight areas that need improvement for the few existing dry port facilities, most of which are undergoing expansion as well as modernization.
\end{abstract}

\section{Keywords}

Dry Port, Dry Port Efficiency, Dry Port Evaluation, Data Envelopment Analysis (DEA) Model

\section{Introduction}

It is usually essential to evaluate the efficiency of any institution so as to establish any sources of inefficiencies. This is useful as a first step in putting measures to ensure improved efficiency in operations in an organization. For any type of or- 
ganization, how efficient the organization is vital if the particular organization is to remain competitive in service delivery against similar institutions. Benchmarking against existing similar organizations might also be necessary to identify potential areas of improvement. In the seaports, different models have been used to evaluate the efficiency of ports in different regions based on similar factors. One of the most commonly used models is the Data Envelopment Analysis (DEA). This model is used in this chapter to evaluate the efficiency of selected dry ports in Africa. It is worth noting that although the dry port concept has been taken up and applied widely in Europe and Asia, on the contrary, it is still in the uptake stages in most African countries. In fact, most of the dry port development projects are either in the planning stages, for instance the construction of dry ports in Togo to serve port of Lome and the Dosso dry port in Niger which is under construction [1]. The Kaduna dry port in Nigeria is an example of one of the dry ports that have been completed but still in the infancy phases of operation [2]. Other dry ports are planned to be constructed in different transport corridors in West Africa. This notwithstanding, there are a few operational dry ports in the continent. Examples are the Modjo and Kalitydry ports in Ethiopia [3], Mombasa dry port in Kenya [4], Isaka dry port in Tanzania and Casablanca dry port in Morocco [5]. Most of these dry ports are as a result of upgrading of existing Inland Container Depot, for instance the dry port of Mombasa in Kenya. In this paper, the efficiencies of above operational dry ports are calculated using DEA model. The paper has the following sections: Literature review, which deals with the previous researches that have applied the DEA model; methodology, which introduces the mathematical formulation of the DEA model; Analysis of the DEA results, which presents the DEA results and provides a discussion on the same and finally the conclusion section.

\section{Literature Review}

DEA is an established statistical technique which measures the relative efficiencies of units where simple efficiency measures are difficult to obtain [6]. The main attraction to DEA is that it can deal with multiple inputs and outputs. The units in any assessment by the DEA model must generally be homogeneous and independent performing the same function. It is a powerful technique especially where there are large numbers of units providing a similar service in relative isolation [7]. The DEA model was first developed as a way of evaluating service units by Charnes et al. [8], based on linking the estimation of technical efficiency and production frontiers [6].

Different variations of the DEA technique have been used to evaluate port efficiency in by numerous researchers. The main attractiveness of DEA is that multiple inputs and outputs can be added to the model, and therefore has the capability of providing an overall evaluation of port performance [9]. Martnez et al. [10] examined the efficiency of 26 Spanish port using DEA-BCC models. They found out that highly complex ports are associated with relatively higher 
efficiency. Similarly, Tonzon [11] analyzed the efficiency of 4 ports in Australia. In addition 12 other international container ports for the year 1996 were included in his work. For this analysis DEA-CCR and DEA additive models were used in the analysis and the author showed that the most inefficient ports sampled included Melbourne, Rotterdam, Yokohama and Osaka. The author further notes that areas of improvement existed in the areas of size and number of container berths, labor inputs and total terminal area. DEA window analysis was applied to 8 Japanese ports for a 10year period between 1990 and 1999 to measure the efficiency variation in major Japanese ports [12]. The ports studied were Tokyo, Yokohama, Kobe and Osaka. Constant efficiency was witnessed for the case of Tokyo, while the other ports had unsteady efficiency scores throughout the period considered.

Baros [13] used DEA to determine the main sources of ports' inefficiencies in Portugal for the years between 1990 and 2000. Although these Portuguese ports showed high levels of technical efficiency over the period under study, technological change had superseded any advancement in the ports sector in Portugal. The authors attributed this high efficiency to the substantial financial aid from the EU's Single Market program. In order to benchmark and compare management practices and strategies for ports in Portugal and Greece, [14] used the DEA model to estimate the relative efficiency of the ports in these two countries. It was noted that economic benefits could be identified and evaluated from such a benchmarking study.

Min and Park [15] used DEA window analysis model to evaluate variation in for 11 container terminals over a period of 4 years. The number of port workers, total quay length, storage size and the number of cranes were used as the input measures, while cargo throughput was used as the output. Similarly, [16] applied cross-sectional data in a DEA model to the compare relative efficiency for a sample of 69 European container terminals. Using data for the year 2002 from ports that met the criteria of annual throughput of over 10,000 twenty foot equivalent units (TEUs), the sample covered 24 European countries. The authors found that European container terminals were relatively inefficient and that large container terminals were more likely to be associated with higher efficiency scores. Furthermore, the authors found significant variations in the average efficiency of container terminals located in different European regions. Terminals in the British Isles were found to be the most efficient with those in Scandinavia and Eastern Europe least efficient.

Although less work has been carried out on the dry ports (Inland ports) compared to the sea ports, there exists some relevant works on dry ports development and evaluation of efficiency. Judit et al. [17] carried out a study to assess the level of development of the European Freight Villages by a method oriented on the benchmarking approach. The authors aimed at assisting in provision of more transparency to the market segment of international logistics centres and are oriented to give a positive impulse to the further successful European devel- 
opment of sustainable macro logistics concepts. The study concludes that the engagement of the public sector in the funding and the strategic planning (overall concept) of the Freight Villages is a crucial factor for the economic sustainable success in the development of such locations. Elshaday [3] used the Supply Chain Operation Reference Model (SCOR) and Queue to perform an analysis of the performance of Mojo and Kality which are the two of the major dry ports in Ethiopia in relation to the intermodal transportation system. The efficiency measurements of a dry port take simultaneously into consideration such aspects as container security, along with annual container throughput. Hercules, et al. [18] applied data envelopment analysis (DEA) technique to analyze the efficiency of the dry ports located in the JNPT region of India. One of their main conclusions is that capital investment is essential for implementing container security. In this paper, this invaluable decision making model is used to determine the efficiency of selected dry ports in Africa. This analysis will be performed over a period of four years based on a range of inputs and with container throughput as the model output. It will serve as a basis for efficiency evaluation as more dry ports are either constructed or upgraded in different countries to meet the logistical demands of the African continent.

\section{Methodology}

This DEA model is a non-parametric method based on application of linear programming for measuring the efficiency of units, referred to Decision-Making Units (DMUs). An input-oriented DEA model, known today as DEA-CCR that assumes constant returns-to-scale was developed by [8]. The DEA-BCC model proposed by Baker et al. [19] assumes variable returns-to-scale. These two approaches of the DEA model have been widely applied to calculate the efficiencies in different sectors of economy. In this paper, the input-based productivity efficiencies of selected dry ports will be investigated. The principle of this non-parametric approach is based on two important sets of multiple variables called inputs and outputs, which are used to derive an efficiency score adjusted to a number less than or equal to 1 , but greater than or equal to 0 . The formulation of the relative efficiency of a DMU was proposed by [8] as shown below:

$$
\begin{gathered}
\max \frac{\sum_{k=1}^{s} u_{k} y_{k p}}{\sum_{j=1}^{m} v_{i} x_{i p}} \\
\text { s.t }=\frac{\sum_{k=1}^{s} u_{k} y_{k i}}{\sum_{j=1}^{s} v_{j} x_{i, j}} \leq 1 \text { and } u_{k} v_{j} \geq 0 \forall k, j
\end{gathered}
$$

where:

$$
\begin{aligned}
& y_{k i}=\text { amount of output } \mathrm{k} \text { produced by } \mathrm{DMU}_{i} \\
& x_{j i}=\text { amount of input, } \mathrm{j} \text { utilized by } \mathrm{DMU}_{i} \\
& u_{k}=\text { weight given to output } \\
& v_{j}=\text { weight given to input } j
\end{aligned}
$$


Converting the computations into linear programming format yields;

$$
\max \sum_{k=1}^{s} u_{k} y_{k p}=\theta_{p}
$$

Subject to: $\sum_{j=1}^{m} v_{j} y_{j p}=1$

$$
\sum_{k=1}^{s} u_{k} y_{k i}-\sum_{j=1}^{m} v_{j} x_{i j} \leq 0 \forall i, u_{k}, v_{j} \geq 0 \forall_{k, j}
$$

The combination of the two models results in the DEA-CCR and DEA-BCC models as shown below: CCR Model max $\phi_{k}$

CCR model: $\quad$ s.t $\sum_{i=1}^{n} \lambda_{j} x_{i j} \leq \phi_{r} x_{i r} i=1,2, \cdots, m$

$$
\begin{gathered}
\sum_{j=1}^{n} \lambda_{j} y_{r k} \leq \phi_{r} x_{i r} r=1,2, \cdots, s \\
\lambda_{j} \geq 0, \forall j
\end{gathered}
$$

BCC model: $\sum_{j=1}^{n} \lambda_{i}=1$

$\phi_{k}$-the efficiency of the $k^{\text {th }}$ DMU.

In this chapter, the Window analysis is used for detecting efficiency trends over time and offers the opportunity to assess how performance of firms evolve through a chain of overlapping windows by considering each port as a different entity in each period under analysis. The model is based on the assumption that what was viable in the past remains viable forever, and that the treatment of time in windows analysis is more in the nature of an averaging over the periods of time covered by the window [20]. An important advantage of window analysis is that its increases the number of units for evaluation and in effect the discriminatory power of the method [21]. In applying window analysis, DEA first evaluates the performance of all DMU's in the same window and the efficiency of each DMU will be entered into the right window position in the table. This procedure is repeated to obtain all efficiency values in every window [22].

\section{Analysis of DEA Results}

The efficiencies of five (5) dry ports in Africa are calculated using the windows analysis approach of the DEA. The selected dry ports are; the Mojo and Kality dry ports in Ethiopia, Mombasa dry port in Kenya, Casablanca dry port in Morocco and the Isaka dry port in Shinyanga area of Tanzania. The choice of input and output variables is very important in the model construction [23] and since the input-output approach is chosen for this work, it is important to define the measures to be used as the inputs and outputs. The inputs are: number of reach stackers, number of forklifts, number of tractors and the total dry port area in square meters. The output measure will be the container throughput in TEUs per annum and the analysis is carried out over a period of four (4) years. The DEA window analysis is used since it can allow the computation of dry port efficiencies over the period being considered in this work [23]. The choice of the five (5) dry ports was majorly based on the capacity of the said dry ports and also availability of the dry port data. Ethiopia is one of the landlocked countries in Africa is mainly served by the Djibouti sea port and has embraced the dry port 
concept. It has a number of operational dry ports, that include Mojo, Kality, Mekele, Semera, Kombolcha, Addis Abeba, Gelan and Dire dawa. The major dry ports amongst these are the Mojo and Kality dry ports and were selected for this study. Figure 1 shows the locations of the dry ports in Ethiopia.

Mombasa and Isaka are the major operational dry ports in the eastern part of Africa. Isaka is located $485 \mathrm{~km}$ from Kigali and 982 from Dares Salaam along the Dar-Mwanza railway line. This dry port provides holding and clearance services for variety of cargo eliminating the need of transportation to and from Dares Salaam for shippers from Uganda, Rwanda, Democratic Republic of Congo, Burundi and Western regions of Tanzania [24]. Mombasa dry port is located at the coastal city of Mombasa in Kenya, approximately $4 \mathrm{Km}$ from the sea port of Mombasa [25]. Casablanca dry port in Morocco is located in city of Casablanca and serves the sea port of Casablanca, which is the largest sea port in Morocco. Table 1 shows the tabulation of the model variables for the five (5) dry ports in the period between years 2014 and 2017.

Table 2 shows the statistics of the variables for the year 2017. Although the model computes similar statistics for all the years under consideration, the results shows that there was no much variation in the input variables, while the container throughput increased gradually. This can be attributed to the increased trade in these African countries, especially with China. This could be one source of inefficiency in most of the dry ports considered, since there is almost stagnated increase in input variables. It is worth noting that major projects on port and dry port development are ongoing across the African continent and this is expected to considerably improve the dry port efficiency. Table 3 shows a correlation analysis for the year 2017. From the table, it can be seen that there a great relationship between the container throughput, which is the model output, number of reach stackers and the number of tractors. This presents an opportunity that can be exploited to improve the efficiencies of the dry ports.

Table 4 shows the results for the analysis and averages for all the dry ports considered over the four (4) years' period. It shows that Mombasa dry port has the highest average of 1 , followed by Casablanca dry port at 0.762 . In this analysis, Kality dry port and Isaka dry ports were found to have the lowest comparative averages of 0.164 and 0.142 respectively. Mombasa dry port serves the Northern transport corridor which originates from Mombasa port and connected to the hinterland by rail and by road network from Kenya to Uganda, Rwanda, Burundi, Southern Sudan and eastern regions of the Democratic Republic of Congo [25]. The pressure from the increased annual container throughput at the port of Mombasa and the competition from the port of Dares Salaam have led to increased investment in the dry port hence the comparatively improved efficiency. The other dry ports considered are also undergoing modernization and it will be interesting to see how their overall efficiency will improve as competition between sea ports and the need for reduced delays at the sea ports and the dry ports increase. 
Table 5 shows the ranking of the dry ports from the analysis which ranks Mombasa dry port as the most efficient among the dry ports considered, followed by the Casablanca dry ports. Isaka dry port is the least efficient as per this analysis. Figure 2 shows the port efficiency variation per term. From this, it can be seen that there is very little variation of efficiencies for the individual ports over the period considered.

Table 1. Input and output variables for the DEA model.

\begin{tabular}{|c|c|c|c|c|c|}
\hline DMU & Variables & 2014 & 2015 & 2016 & 2017 \\
\hline \multirow[t]{5}{*}{ Mojo } & $\begin{array}{l}\text { Container } \\
\text { Throughput }\end{array}$ & 77,012 & 84,196 & 91,773 & 100,033 \\
\hline & No. of reach stackers & 10 & 10 & 10 & 11 \\
\hline & No. of forklifts & 15 & 15 & 16 & 16 \\
\hline & No. of Tractors & 9 & 9 & 10 & 10 \\
\hline & Total area & 640,000 & 640,000 & 640,000 & 640,000 \\
\hline \multirow[t]{5}{*}{ Casablanca } & $\begin{array}{l}\text { Container } \\
\text { Throughput }\end{array}$ & 98,280 & 120,000 & 129,600 & 143,338 \\
\hline & No. of reach stackers & 8 & 9 & 9 & 11 \\
\hline & No. of forklifts & 13 & 13 & 13 & 13 \\
\hline & No. of Tractors & 15 & 15 & 15 & 15 \\
\hline & Total area & 80,000 & 80,000 & 80,000 & 80,000 \\
\hline \multirow[t]{5}{*}{ Isaka } & $\begin{array}{l}\text { Container } \\
\text { Throughput }\end{array}$ & 12,620 & 13,882 & 15,409 & 17,258 \\
\hline & No. of reach stackers & 5 & 6 & 6 & 7 \\
\hline & No. of forklifts & 10 & 11 & 11 & 11 \\
\hline & No. of Tractors & 7 & 7 & 8 & 8 \\
\hline & Total area & 60,000 & 60,000 & 60,000 & 60,000 \\
\hline \multirow[t]{5}{*}{ Mombasa } & $\begin{array}{l}\text { Container } \\
\text { Throughput }\end{array}$ & 190,000 & 205,200 & 217,512 & 238,611 \\
\hline & No. of reach stackers & 11 & 12 & 12 & 14 \\
\hline & No. of forklifts & 12 & 12 & 12 & 13 \\
\hline & No. of Tractors & 14 & 14 & 14 & 14 \\
\hline & Total area & 100,000 & 100,000 & 100,000 & 100,000 \\
\hline \multirow[t]{5}{*}{ Kality } & $\begin{array}{l}\text { Container } \\
\text { Throughput }\end{array}$ & 9526 & 10,684 & 11,806 & 13,105 \\
\hline & No. of reach stackers & 4 & 4 & 4 & 6 \\
\hline & No. of forklifts & 13 & 13 & 13 & 13 \\
\hline & No. of Tractors & 4 & 4 & 4 & 6 \\
\hline & Total area & 350,000 & 350,000 & 350,000 & 350,000 \\
\hline
\end{tabular}


Table 2. Statistics of the model measures for year 2017.

\begin{tabular}{cccccc}
\hline & $\begin{array}{c}\text { No. of Reach } \\
\text { Stackers }\end{array}$ & $\begin{array}{c}\text { No. of } \\
\text { Forklifts }\end{array}$ & $\begin{array}{c}\text { No. of } \\
\text { Tractors }\end{array}$ & $\begin{array}{c}\text { Total } \\
\text { Area }\end{array}$ & $\begin{array}{c}\text { Container } \\
\text { Throughput }\end{array}$ \\
\hline Max & 14 & 16 & 15 & 640,000 & 238,611 \\
Min & 6 & 12 & 6 & 10,000 & 13,105 \\
Average & 9.8 & 13.4 & 10.4 & 228,000 & 102,469 \\
SD & 2.925747768 & 1.356465997 & 3.611094017 & $237,604.7138$ & $84,211.27292$ \\
\hline
\end{tabular}

Table 3. Correlation analysis between model measures for year 2017.

\begin{tabular}{cccccc}
\hline & $\begin{array}{c}\text { No. of } \\
\text { Reach Stackers }\end{array}$ & $\begin{array}{c}\text { No. of } \\
\text { Forklifts }\end{array}$ & $\begin{array}{c}\text { No. of } \\
\text { Tractors }\end{array}$ & Total Area & $\begin{array}{c}\text { Container } \\
\text { Throughput }\end{array}$ \\
\hline $\begin{array}{c}\text { No. of Reach Stackers } \\
\text { No. of Forklifts }\end{array}$ & 1 & 0.322525588 & 0.878359491 & -0.17031769 & 0.970927363 \\
No. of Tractors & 0.878359491 & 0.089826602 & 1 & -0.37202235 & 0.895774537 \\
Total Area & -0.170317694 & 0.871230638 & -0.37202235 & 1 & -0.333031812 \\
Container & 0.970927363 & 0.136397068 & 0.895774537 & -0.33303181 & 1 \\
Throughput & & & & & \\
\hline
\end{tabular}

Table 4. Results of the window analysis.

\begin{tabular}{|c|c|c|c|c|c|}
\hline & 2014 & 2015 & 2016 & 2017 & Average \\
\hline \multirow[t]{4}{*}{ Mojo } & 0.607989 & & & & \\
\hline & & 0.615468 & & & \\
\hline & & & 0.569594 & & \\
\hline & & & & 0.586923 & 0.594994 \\
\hline \multirow[t]{4}{*}{ Casablanca } & 0.711237 & & & & \\
\hline & & 0.779727 & & & \\
\hline & & & 0.794439 & & \\
\hline & & & & 0.764551 & 0.762488 \\
\hline \multirow[t]{4}{*}{ Isaka } & 0.146126 & & & & \\
\hline & & 0.135302 & & & \\
\hline & & & 0.141684 & & \\
\hline & & & & 0.144654 & 0.141942 \\
\hline \multirow[t]{4}{*}{ Mombasa } & 1 & & & & \\
\hline & & 1 & & & \\
\hline & & & 1 & & \\
\hline & & & & 1 & 1 \\
\hline \multirow[t]{4}{*}{ Kality } & 0.169212 & & & & \\
\hline & & 0.175724 & & & \\
\hline & & & 0.183186 & & \\
\hline & & & & 0.128151 & 0.164068 \\
\hline Average & 0.526913 & 0.541244 & 0.537781 & 0.524856 & \\
\hline
\end{tabular}


Table 5. Dry port efficiency ranking.

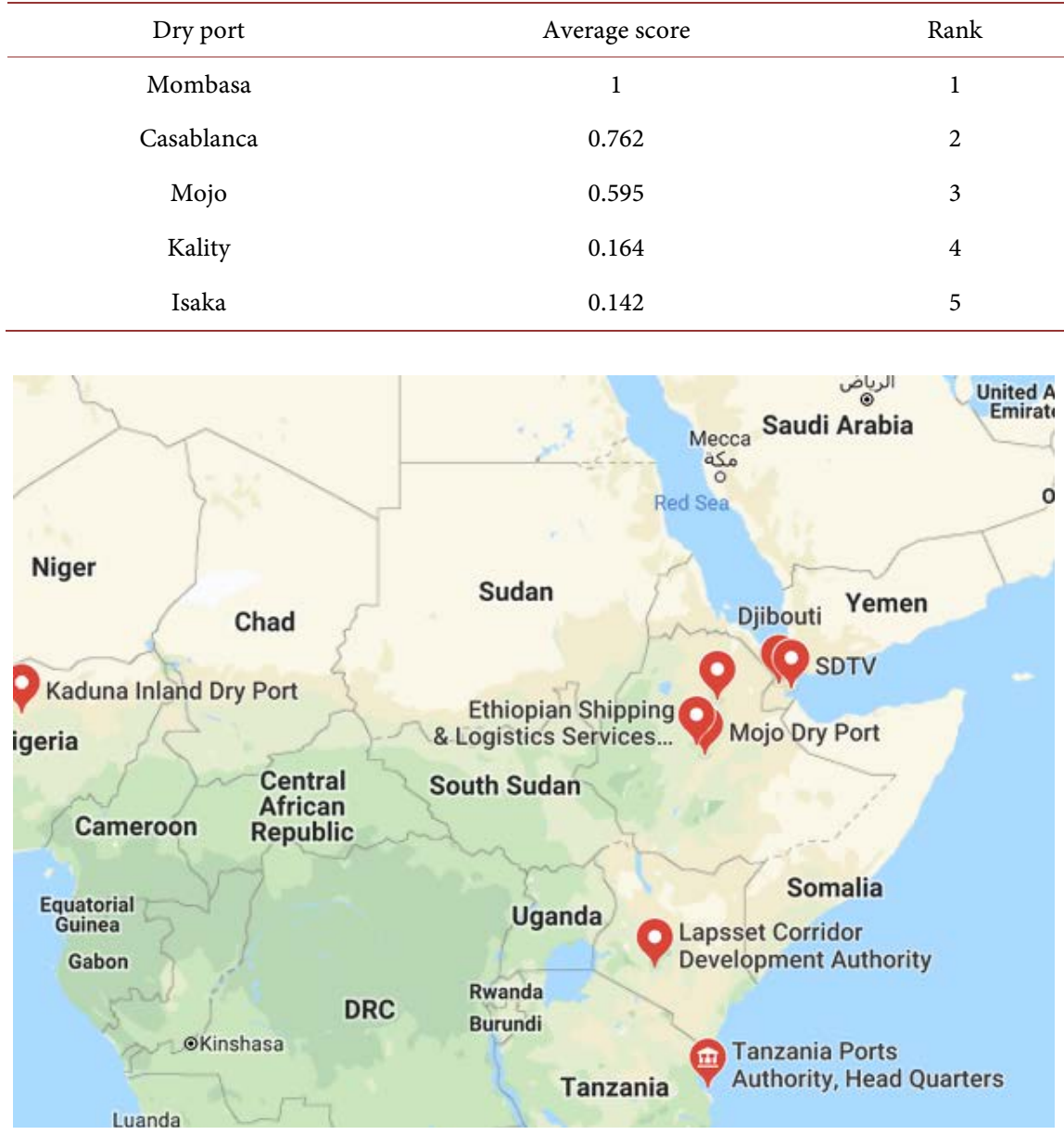

Figure 1. Dry port locations in Ethiopia [3].

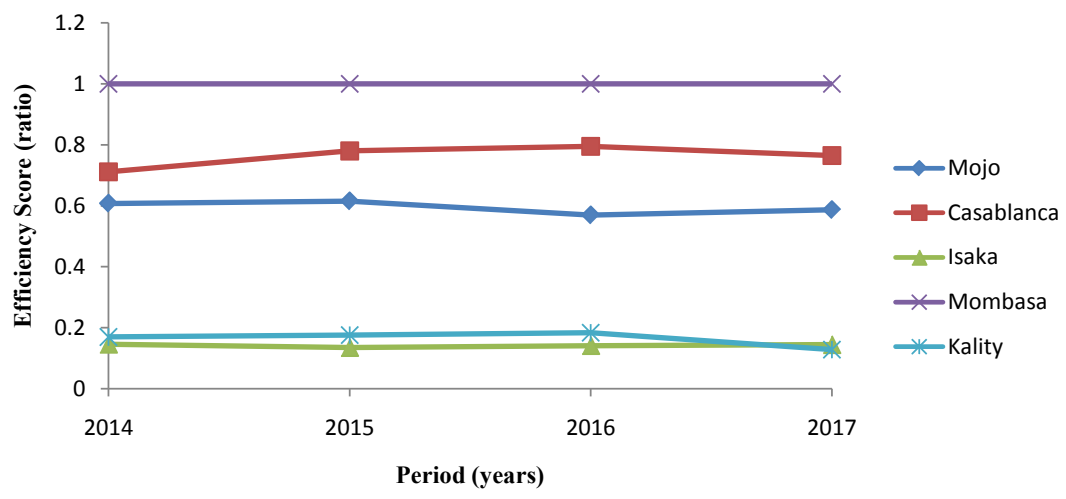

Figure 2. Dry port efficiency variation by term.

\section{Conclusion}

This work considered five (5) dry ports in Africa over a period of four (4) years. The efficiencies of the dry ports were modeled using DEA window analysis using dry port container throughput per annum as the output with other variables as the inputs. The analysis results show that there is a little variation on efficiency 
for all the dry ports over the period considered in this work. This could indicate that little attention has been given to the dry ports, although most of them are in the process of modernization. From the analysis, Mombasa dry port was found to be the most efficient amongst the dry ports considered, maintaining an average score of 1 . Dry ports of Casablanca were ranked second with an average score of 0.762 , while Mojo, Kality and Isaka followed in that order with average scores of $0.595,0.164$ and 0.142 respectively. This research serves as a basis for more investigation in the dry port sector in Africa, one potential area that could be investigated in the relationship between sea port modernization and dry port efficiency. There is also room to increase the number of dry ports and variables and examine how the efficiencies will be affected.

\section{Acknowledgements}

The authors would like to acknowledge the support of Shanghai Maritime University, School of Economics and Management.

\section{Conflicts of Interest}

The authors declare no conflicts of interest regarding the publication of this paper.

\section{References}

[1] PIDG (2015) PIDG Project Fact Sheet Africa: Niger Dry Port.

[2] Council, N.S. (2016) Dry Ports. https://www.shipperscouncil.gov.ng/inland-dry-port

[3] Elshaday, W.G. (2016) Assessment of the Performance of Dry Ports in Ethiopia Using SCOR Method. Addis Ababa Institute of Technology, Addis Ababa.

[4] World Port Source. http://www.worldportsource.com/ports/commerce/KEN_Port_of_Mombasa_1365. php

[5] Bentaleb, F., Mouhsene, F., Charif, M. and Alami, S. (2016) Dry Port-Seaport System Development: Application of the Product Life Cycle Theory. Journal of Transportation and Logistics, 1, 115-128. https://doi.org/10.22532/jtl.267840

[6] Farrell, M. (1957) Measurement of Productive Efficiency. Journal of Royal Statistical Efficiency, 120, 253-281. https://doi.org/10.2307/2343100

[7] Szczepura, A., Davis, C., Fletcher, J. and Bousoffiane, A. (1992) Applied Data Envelopment Analysis in Healthcare: The Relative Efficiency of NHS General Practices. Warwick Business School Research Bureau, Coventry.

[8] Charnes, A., Cooper, W. and Rhodes, E. (1978) Measuring the Efficiency of Decision Making Units. European Journal of Operational Research, 2, 429-444. https://doi.org/10.1016/0377-2217(78)90138-8

[9] Wang, T., Song, D.-W. and Cullinane, K. (2003) Container Port Production Efficiency: A Comparative Study of DEA and FDH Approaches. Journal of the Eastern Asia Society for Transportation Studies, 5, 698-713.

[10] Martinez, B.E., Diaz, A.R., Navarro, I.M. and Ravelo, M.T. (1999) A Study of the Efficiency of Spanish Port Authorities Using Data Envelopment Analysis. Interna- 
tional Journal of Transport Economics, 26, 237-257.

[11] Tongzon, J. (2001) Efficiency Measurement of Selected Australian and Other International Ports Using DEA. Transportation Research Part A: Policy and Practice, 35, 107-122. https://doi.org/10.1016/S0965-8564(99)00049-X

[12] Itoh, H. (2002) Efficiency Changes at Major Container Ports in Japan: A Window Application of Data Envelopment Analysis. Review of Urban and Regional Development Studies, 14, 133-152. https://doi.org/10.1111/1467-940X.00052

[13] Baros, C. (2003) The Measurement of Efficiency of Portuguese Seaport Authorities with DEA. International Journal of Transport Economics, 30, 335-354.

[14] Barros, C. and Athanassiou, M. (2004) Efficiency in European Seaports with DEA: Evidence from Greece and Portugal. Maritime Economics and Logistics, 6, 122-140. https://doi.org/10.1057/palgrave.mel.9100099

[15] Min, H. and Park, B. (2005) Evaluating the Inter-Temporal Efficiency Trends of International Container Terminals Using Data Envelopment Analysis. International Journal of Integrated Supply Management, 1, 258-277. https://doi.org/10.1504/IJISM.2005.005950

[16] Cullinane, K. and Wang, T. (2006) The Efficiency of European Container Ports: A Cross-Sectional Data Envelopment Analysis. International Journal of Logistics Research and Applications, 9, 19-31. https://doi.org/10.1080/13675560500322417

[17] Judit, O., Steffen, N., Thomas, N. and József, P. (2018) Ranking of Dry Ports in Europe-Benchmarking. Periodica Polytechnica Transportation Engineering, 46, 95-100.

[18] Hercules, H., Girish, G. and Mukul, J. (2011) Dry Port Efficiency and Container Security. IAME Latin America, Santiago, 26-28 October 2011, 1-16.

[19] Banker, R., Charnes, A. and Cooper, W. (1984) Some Models for Estimating Technical and Scale Inefficiencies in Data Envelopment Analysis. Management Science, 30, 1078-1092. https://doi.org/10.1287/mnsc.30.9.1078

[20] Tulkens, H. and Van den Eeckhaut, P. (1995) Non-Frontier Measures of Efficiency, Progress and Regress for Time Series Data. International Journal of Production Economics, 33, 83-97. https://doi.org/10.1016/0925-5273(95)00002-6

[21] Pjevčević, D., Radonjić, A., Hrle, Z. and Čolić, V. (2012) DEA Window Analysis for Measuring Port Efficiencies in Serbia. PROMET-Traffic \& Transportation, 24, 63-72. https://doi.org/10.7307/ptt.v24i1.269

[22] Chung, S., Lee, A., Kang, H. and Lai, C. (2008) A DEA Window Analysis on the Product Family Mix Selector for Semi-Conductor Fabricator. Expert Systems with Applications, 35, 379-388. https://doi.org/10.1016/j.eswa.2007.07.011

[23] George, K.V. (2015) Assessment of Port Efficiency in West Africa Using Data Envelopment Analysis. American Journal of Industrial and Business Management, 5, 208-218. https://doi.org/10.4236/ajibm.2015.54023

[24] Citizen (2013) Isaka Dry Port on Track. The Citizen Newspaper. https://www.thecitizen.co.tz/News/Isaka-dry-port-project-remains-on-track/184034 0-1990596-irr9jm/index.html

[25] Gerald, W.W. and Jin, Z. (2015) A Comparative Study of Dry Ports in East Africa and China. IISTE, 7-17. 